\title{
Retraction: Five papers from Open Access Maced J Med Sci. Vol. 7 No. 18 (2019): Sep 30 (Global Dermatology)
}

\author{
Mirko Spiroski* \\ Scientific Foundation SPIROSKI, Skopje, Republic of Macedonia
}

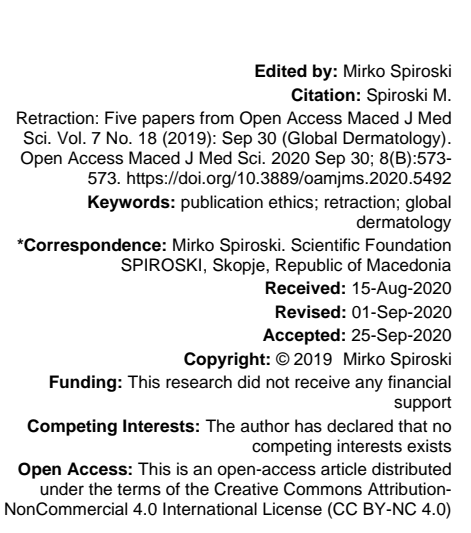

\begin{abstract}
Editor-in-Chief has retracted the following articles from the special issue Vol. 7 No. 18 (2019): Sep 30 (Global Dermatology): (1) DNA Waves and Their Applications in Biology - Massimo Fioranelli et al. - Open Access Macedonian Journal of Medical Sciences (2019) - DOI: 10.3889/oamjms.2019.767; (2) Recovery of Brain in Chick Embryos by Growing Second Heart and Brain - Massimo Fioranelli et al. - Open Access Macedonian Journal of Medical Sciences (2019) DOI: 10.3889/oamjms.2019.777; (3) A Mathematical Model for the Signal of Death and Emergence of Mind Out of Brain in Izhikevich Neuron Model - Massimo Fioranelli et al. - Open Access Macedonian Journal of Medical Sciences (2019) - DOI: 10.3889/oamjms.2019.774; (4) A Black Hole at the Center of Earth Plays the Role of the Biggest System of Telecommunication for Connecting DNAs, Dark DNAs and Molecules of Water on 4+N- Dimensional Manifold - Massimo Fioranelli et al. - Open Access Macedonian Journal of Medical Sciences (2019) - DOI: 10.3889/oamjms.2019.776 (5) New System Delivering Microwaves Energy for Inducing Subcutaneous Fat Reduction: In - Vivo Histological and Ultrastructural Evidence - Nicola Zerbinati et al., Open Access Macedonian Journal of Medical Sciences (2019) - DOI: 10.3889/oamjms.2019.778

An internal investigation has raised sufficient evidence that they are not directly connected with the special issue Global Dermatology and contain inconsistent results. As such, we retract these articles from the literature and by guidelines and best editorial practices from the Committee on Publication Ethics. We apologize to our audience about this unfortunate situation.
\end{abstract}

Editor-in-Chief has retracted five articles from the special issue Vol. 7 No. 18 (2019): Sep 30 (Global Dermatology) [1], [2], [3], [4], [5].

An internal investigation has raised sufficient evidence that they are not directly connected with the special issue Global Dermatology and contain inconsistent results. Several co-authors requested to be excluded from the author list. As such, we retract these articles from the literature and by guidelines and best editorial practices from the Committee on Publication Ethics. We apologize to our audience about this unfortunate situation.

\section{References}

1. Fioranelli M, Sepehri A, Roccia MG, Rossi C, Lotti J, Vojvodic P Barygina V, Vojvodic A, Vlaskovic-Jovicevic T, Peric-Hajzler Z, Matovic D, Vojvodic J, Dimitrijevic S, Sijan G, Wollina U, Tirant M, Van Thuong N, Lotti T. DNA Waves and Their Applications in Biology. Open Access Maced J Med Sci. 2019 Sep 30; 7(18):30963100. https://doi.org/10.3889/oamjms.2019.767

2. Fioranelli M, Sepehri A, Roccia MG, Linda C, Rossi C, Dawodo A, Vojvodic P, Lotti J, Barygina V, Vojvodic A, Wollina U, Tirant M,
Van Thuong N, Lotti T. Recovery of Brain in Chick Embryos by Growing Second Heart and Brain. Open Access Maced J Med Sci. 2019 Sep 30; 7(18):3085-3089. https://doi.org/10.3889/oamjms.2019.777

3. Fioranelli M, Sepehri A, Roccia MG, Rossi C, Lotti J, Barygina V, Vojvodic P, Vojvodic A, Vlaskovic-Jovicevic T, Vojvodic J, Dimitrijevic S, Peric-Hajzler Z, Matovic D, Sijan G, Wollina U, Tirant M, Van Thuong N, Lotti T. A Mathematical Model for the Signal of Death and Emergence of Mind Out of Brain in Izhikevich Neuron Model. Open Access Maced J Med Sci. 2019 Sep 30; 7(18):3121. 3126. https://doi.org/10.3889/oamjms.2019.774

4. Fioranelli M, Sepehri A, Roccia MG, Linda C, Rossi C, Vojvodic P, Lotti J, Barygina V, Vojvodic A, Wollina U, Tirant M, Van Thuong $\mathrm{N}$, Lotti T. A Black Hole at the Center of Earth Plays the Role of the Biggest System of Telecommunication for Connecting DNAs, Dark DNAs and Molecules of Water on 4+N- Dimensional Manifold. Open Access Maced J Med Sci. 2019 Sep 30; 7(18):3073-3080. https://doi.org/10.3889/oamjms.2019.776

5. Zerbinati N, d'Este E, Cornaglia Al, Riva F, Farina A, Calligaro A, Gallo G, Perrotta ER, Protasoni M, Bonan P, Vojvodic A, Fioranelli M, Van Thuong N, Lotti T, Tirant M, Vojvodic P. New System Delivering Microwaves Energy for Inducing Subcutaneous Fat Reduction: In - Vivo Histological and Ultrastructural Evidence. Open Access Maced J Med Sci. 2019 Sep 30; 7(18):2991-2997. https://doi.org/10.3889/oamjms.2019.778 